\title{
Microbiology neutralization of zearalenone using Lactococcus lactis and Bifidobacterium sp.
}

\author{
A. Król ${ }^{1}$ • P. Pomastowski ${ }^{1}$ - K. Rafińska ${ }^{1}$ - V. Railean-Plugaru ${ }^{1} \cdot$ J. Walczak $^{1}$. \\ B. Buszewski ${ }^{1}$
}

Received: 27 April 2017 /Revised: 17 July 2017 / Accepted: 31 July 2017 /Published online: 29 August 2017

(C) The Author(s) 2017. This article is an open access publication

\begin{abstract}
The aim of the study was to neutralize zearalenone by lactic acid bacteria (LAB) such as Lactococcus lactis and Bifidobacterium sp. and investigate the mechanism of zearalenone (ZEA) binding. Neutralization of ZEA by LAB was confirmed by identification of binding kinetics and spectroscopic studies such as Fourier transform infrared spectroscopy (FT-IR) and matrix-assisted laser desorption/ionization time-of-flight mass spectrometry (MALDI-TOF-MS). The obtained results showed that the kinetic process of zearalenone binding to L. lactis is not homogeneous but is expressed with an initial rapid stage with about $90 \%$ of ZEA biosorption and with a much slower second step. In case of Bifidobacterium sp., the neutralization process is homogeneous; the main stage can be described with about $88 \%$ of ZEA biosorption. MALDI-TOF-MS measurements and FTIR analysis confirmed the uptake of zearalenone molecules by bacterial species. Moreover, the assessment of dead and live lactic acid bacteria cells after zearalenone treatment was performed using fluorescence microscopy.
\end{abstract}

Keywords Zearalenone $\cdot$ Toxicity $\cdot$ Neutralization $\cdot$ Lactic acid bacteria

Published in the topical collection celebrating $A B C$ s 16th Anniversary.

B. Buszewski

bbusz@chem.umk.pl

1 Faculty of Chemistry, Centre for Modern Interdisciplinary Technologies, Nicolaus Copernicus University, 7 Gagarina Str, 87-100 Torun, Poland

\section{Introduction}

The Fusarium family is an important cereal pathogen worldwide because of its ability to produce toxic secondary metabolites (mycotoxins) [1]. After infection, mycotoxins can accumulate into cereal plant, resulting in contamination of animal feed and human cereal food in toxicologically relevant concentrations [2]. The main mycotoxins found in agricultural products are aflatoxins (AFs), zearalenone (ZEA), deoxynivalenol, and its derivatives, fumonisins, patulin, and ochratoxin A (OTA) [3]. Zearalenone is produced by Fusarium fungi, including Fusarium graminearum, Fusarium culmorum, Fusarium cerealis, Fusarium equiseti, and Fusarium semitectum [4]. Mostly, this mycotoxin is present in corn, but it can be also found in other important crops such as wheat, barley, sorghum, and rye throughout various countries of the world [5]. Chemically, zearalenone is a resorcyclic acid lactone described as 6-[10-hydroxy-6-oxotrans-1-undecenyl]-B-resorcyclic acid lactone (Fig. 1a) [6]. ZEA has structural similarity to the natural estrogens, so it can mimic endogenous estrogens, antagonize their activity, change their mechanism of synthesis and metabolism, or interfere with the synthesis of receptor, which contributes to change and neoplastic, i.e., breast cancer or prostate cancer. The biotransformation of ZEA in animals involves the formation of two major metabolites, $\alpha$-zearalenol and $\beta$-zearalenol $(\alpha-Z O L$ and $\beta$-ZOL); alpha zearalenol shows higher estrogenicity than ZEA, but $\beta-Z O L$ is less estrogenic $[7,8]$. ZEA derivatives are shown in Fig. 1.

Concerning the importance and diversity of their toxic effects, the occurrence of mycotoxins in foods is potentially dangerous for public health and it is also considered as a major economic problem [9]. Physical and chemical methods have been developed to control the occurrence of these microorganisms and their toxins, but no efficient strategy has yet been 
Fig. 1 Chemical structures of ZEA and its derivatives: (A) zearalenone (ZEA), (B) $\alpha$ zearalenol $(\alpha-Z \mathrm{ZL}),(\mathbf{C}) \beta$ zearalenol $(\beta-\mathrm{ZOL})$; based on $[6]$

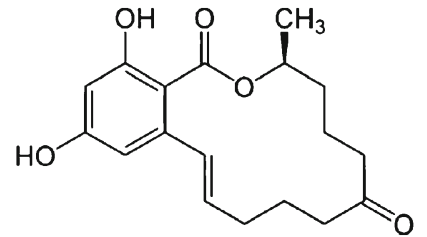

Zearalenone (A)

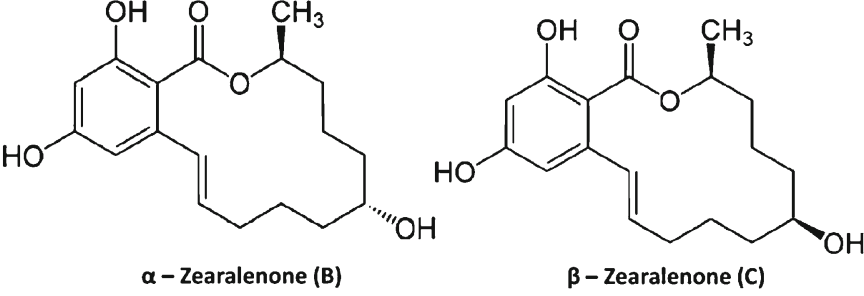

proposed to reduce the presence of mycotoxins. There are a few methods which have been developed to control the occurrence of Fusarium and their toxins, i.e., physical and chemical approaches [10, 11]. Unfortunately, they are non-efficient and contribute to changes in the value of food products, the organoleptic properties of the purified substance, and the occurrence of toxic substances residues [12]. In the last 10 years, microbiological methods have received much attention [12-21]. They have been found to be safer, more effective, and not inducing harmful side effects that could adversely affect the health and life of humans and animals [22]. One of the most promising organisms able to ZEA neutralization seems to be lactic acid bacteria (LAB). These microorganisms are widely used for the production of fermented foods and are also part of intestinal microflora. Moreover, a lot of reports indicate that LAB have beneficial health effects in humans [22-24]. Recently, researches have been trying to investigate if the lactic acid bacteria, among other unique properties, are able to bind mycotoxins and neutralize them. Some authors reported that specific strains of LABs, such as Lactobacillus rhamnosus, Lactobacillus plantarum, or Lactobacillus acidophilus can reduce concentration of mycotoxins present in food and feed $[20,25,26]$. There are also some reports of neutralization by others microorganism such as Saccharomyces cerevisiae, Bacillus subtilis, Pseudomonas sp., or Rhizopus strains [14-16, 27]. Therefore, neutralization of zearalenone by lactic acid bacteria could be an interesting alternative to physical and chemical methods because of LAB's strong antimicrobial properties of produced bacteriocins and bioactive sorption of xenoestrogenes. Fuchs et al. [17] have examined detoxification of patulin (PAT) and ochratoxin A (OTA) by L. acidophilus and Bifidobacterium animalis. Results of experiment indicated that both strains are highly effective; L. acidophilus caused a decrease about 95\% of OTA and Bifidobacterium reduced the level of PAT by $80 \%$. However, the antifungal activity of lactic strains is still under debates because there is a limited number of reports which have shown results of using $\mathrm{LAB}$ in the control of mold growth and neutralization of ZEA [25-27]. Due to this fact, development of new microbiology mycotoxins neutralization method is desirable.

In this paper, a novel approach of zearalenone neutralization by lactic acid bacteria such as L. lactis and Bifidobacterium sp. is investigated. What is more, the physicochemical study of neutralization and mechanism of ZEA binding is described.

\section{Materials and methods}

\section{Biological material}

The two strains of lactic acid bacteria (L. lactis and Bifidobacterium sp.) were isolated from milk products (Dairy Cooperative in Drzycim, Poland) according to [28]. The LAB strains were cultured in Tryptone Soya Agar (Soybean Casein Digest Medium, Oxoid, Basingstoke, UK) and M9 (Sigma-Aldrich, Warsaw, Poland). Other chemicals, i.e., zearalenone, dimethyl sulfoxide, $\alpha$-cyano-4hydroxycinnamic acid, acetonitrile, formic acid, phosphatebuffered saline, ethanol, acridine orange, and ethidium bromide, were obtained from Sigma-Aldrich (Warsaw, Poland).

\section{Preparation of lactic bacterial cells modified by zearalenone}

L. lactis and Bifidobacterium sp. strain were cultured in $150 \mathrm{~mL}$ of sterile M9 medium with $6 \mathrm{~mL}$ of $10 \%$ glucose (final concentration of glucose was $0.4 \%$ ). The culture of LAB was incubated with shaking at $37{ }^{\circ} \mathrm{C}$ for $24 \mathrm{~h}$. Thereafter, $2 \mathrm{ml}$ of each culture at $3.26 \mathrm{McF}$ arland $\left(9.78 \times 10^{8} \mathrm{CFU} / \mathrm{mL}\right)$ and $3.67 \mathrm{McF}$ arland $\left(11.01 \times 10^{8}\right.$ $\mathrm{CFU} / \mathrm{mL}$ ) was transferred into new sterile glass tubes. To them, $50 \mu \mathrm{L}$ of ZEA (in dimethyl sulfoxide) to final concentration $130 \mu \mathrm{g} / \mathrm{mL}\left(\mathrm{C}_{0}\right)$ was added. Probes were incubated with shaking at $37{ }^{\circ} \mathrm{C}$ in time intervals $0,10,20,60,120$, 180, 360, 720, 1140, and $1200 \mathrm{~min}$. After mentioned time, the reaction was stopped and optical density (OD) of samples was measured. In order to separate supernatant from bacterial pellet, the samples were centrifuged (4 min, 13,000 rpm). Obtained pellets were used in Fourier transform infrared spectroscopy (FT-IR) and matrix-assisted laser desorption/ ionization time-of-flight mass spectrometry (MALDI-TOFMS) analysis and for the determination of cells viability by fluorescence microscopy. Content of ZEA in supernatants was measured by liquid chromatography electrospray ionization tandem mass spectrometry approach (LC-ESI-MS/MS). 


\section{Fourier transform infrared spectroscopy analysis}

FT-IR analysis was performed with a Direct Detect Merck Millipore spectrophotometer (Germany). In total, $2 \mu \mathrm{L}$ of sample was pressed into a card and dried. All IR spectra were recorded at room temperature in range of $1350-1850 \mathrm{~cm}^{-1}$.

\section{Matrix-assisted laser desorption/ionization with mass spectrometry analysis}

Bacterial cells bound by zearalenone were extracted with ethanol and formic acid; bacterial pellet was centrifuged (4 min, 13,000 rpm) and supernatant was decanted. To obtained pellet, $300 \mu \mathrm{L}$ of water and $900 \mu \mathrm{L}$ of ethanol were added. All samples were centrifuged ( $2 \mathrm{~min}, 13,000 \mathrm{rpm}$ ), and the supernatant were separated. Then, $2 \mu \mathrm{L}$ of $70 \%$ formic acid and $2 \mu \mathrm{L}$ of acetonitrile were added; all samples were centrifuged ( $2 \mathrm{~min}, 13,000 \mathrm{rpm}$ ) again. In total, $0.75 \mu \mathrm{L}$ of each sample was spotted on MALDI-TOF-MS MTP AnchorChip 384 in triplicate. For the next spots, $0.75 \mu \mathrm{L}$ of zearalenone at concentration $5 \mathrm{mg} / \mathrm{mL}$ was added (also in triplicate). Next, $\alpha$ cyano-4-hydroxycinnamic acid (HCCA) matrix at concentration $10 \mathrm{mg} / \mathrm{mL}$ was prepared; $1.5 \mathrm{mg}$ of HCCA was dissolved in $150 \mu \mathrm{L}$ of standard solution $\left(50 \% \mathrm{ACN}, 47.5 \% \mathrm{H}_{2} \mathrm{O}\right.$, and $2.5 \%$ TFA). After drying, $0.75 \mu \mathrm{L}$ of prepared matrix was spotted on each spot and dried again. Samples were analyzed in reflective positive ionization mode in the $400-2800 \mathrm{~m} / \mathrm{z}$ range. MS spectra were recorded on Ultraflex Extreme II spectrometer with smart beam laser $(\lambda=355 \mathrm{~nm}, 2 \mathrm{kHz}$ frequency). FlexControl and FlexAnalysis software were used for evaluation of spectrometric data.

\section{Determination of cells viability after ZEA neutralization}

After 60 and 180 min of incubation, acridine orange $\left(\lambda_{\text {exc }}=503 \mathrm{~nm}, \lambda_{\mathrm{em}}=530 / 540 \mathrm{~nm}\right)$ and ethidium bromide $\left(\lambda_{\text {exc }}=493 \mathrm{~nm}, \lambda_{\mathrm{em}}=620 \mathrm{~nm}\right)$ at final concentration of 0.12 and $0.4 \mu \mathrm{g} / \mathrm{mL}$, respectively, were added to the samples and incubated for $5 \mathrm{~min}$ in room temperature. Next, the bacterial suspension was centrifuged (4 min, $4000 \mathrm{rpm}$ ) and bacterial pellet were dissolved in phosphate-buffered saline (PBS, $1 \times$ ). Control (bacterial cells without zearalenone) was also performed. All samples were stored in the dark. Determination of LAB viability after ZEA neutralization was carried out using fluorescence microscope Zeiss Axiocom D1 (Germany); set of filters $43 \mathrm{He}$ and 38 were used. Recorded images were analyzed with Axio Vision 4.8. software.

\section{High-performance liquid chromatography analysis}

The Shimadzu HPLC system (Tokyo, Japan), equipped with a binary solvent delivery system (LC-30AD), SPD-M20A UV diode array detector, autosampler (SIL-30AC), column thermostat (CTO-20AC), and data acquisition station, was used for the chromatographic analyses. For instrument control, data acquisition and processing LabSolution 5.8 software was used.

Zearalenone was separated using ACE C8 column dimensions of $150 \times 4.6 \mathrm{~mm}$ and $5 \mu \mathrm{m}$ particle size. The mobile phase consisted of $0.1 \%$ formic acid in deionized water and acetonitrile (60:40). The flow rate was $0.6 \mathrm{~mL} / \mathrm{min}$, the injection volume was $1 \mu \mathrm{L}$, separation temperature was $40^{\circ} \mathrm{C}$, and absorbance was measured at $\lambda=270 \mathrm{~nm}$. The method was validated under optimized conditions. The calibration curve for zearalenone was linear over the concentration range $0.01-$ $1000 \mu \mathrm{g} / \mathrm{mL}$. The concentration range was obtained with the regression curve $(\mathrm{y}=\mathrm{ax}+\mathrm{b})$ and correlation coefficient $\left(R^{2}\right)$ was 0.998 . The percentage of ZEA adsorbed by LAB cells was calculated using Eq. (1).

$E \%=\frac{100^{*}\left(C_{0}-C\right)}{C_{0}}$

where $C_{0}$ is an initial concentration of zearalenone and $C$ is the concentration of zearalenone at the appointed time. The experimental kinetic data were modeled using the zero-order kinetic model based on the following equation:

$C=C_{0}-k^{*} t$

where $C_{0}$ is the initial concentration of ZEA expressed in $\mu \mathrm{g}$ / $\mathrm{mL}, C$ is $\mathrm{ZEA}$ concentration $(\mu \mathrm{g} / \mathrm{mL})$ in aqueous phase at time $t, t$ is the time of zearalenone binding process $(\mathrm{min})$, and $k(\mu \mathrm{g} /$ $\left.\mathrm{mL} \min ^{-1}\right)$ is constant rates of the zero-order kinetic model.

\section{Results}

\section{Kinetic study of ZEA binding to lactic acid bacteria}

In order to monitor the kinetic mechanism of ZEA binding to lactic acid bacteria, the concentration of ZEA in the supernatant after biosorption by LAB in the function of time was measured. Results of performed kinetic study are important information for better understanding the factors that influence the rates of the binding process. The obtained experimental kinetic data were tested against the zero-order kinetic models to determine the constant of ZEA uptake rate and to characterize the possible binding mechanism of zearalenone by lactic acid bacteria. To determine the concentration of zearalenone, the high performance liquid chromatography was performed.

The decrease of ZEA concentration in solution and the efficiency of zearalenone binding to L. lactis, as a function of time, have been shown in Fig. 2. The kinetic measurements showed that concentration of zearalenone decreased with increasing incubation time and the kinetic curve was expressed by two different stages: the first one is quite rapid stage of 


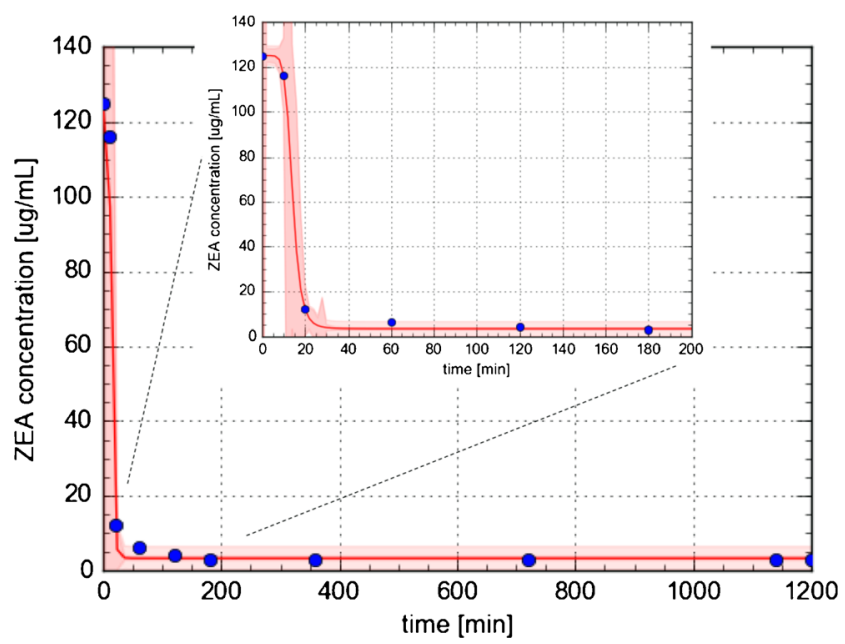

Fig. 2 Kinetics of zearalenone binding by Lactococcus lactis; standard deviation $(\mathrm{SD})$ is shown as a red shadow

zearalenone biosorption, and the second stage undergo system to equilibrium. Rapid decrease in zearalenone concentration in samples was observed during the first $20 \mathrm{~min}$ of the experiment, then the uptake rate of ZEA by L. lactis was significantly reduced to finally achieve the equilibrium. About $90 \%$ of zearalenone was bound by LAB in the first kinetic stage and additionally about $7 \%$ in the second stage. Then the system reached equilibrium. The calculated constant rate of the zeroorder kinetic model had the value of 5.49 and $0.15 \mu \mathrm{g} / \mathrm{mL}$ $\min ^{-1}$ for first and second stage of biosorption process, respectively.

Neutralization of zearalenone by Bifidobacterium sp. is also characterized by a significant decrease ZEA concentration in solution in time (Fig. 3), and two stages of biosorption process can be divided. In the first one, lasting first $720 \mathrm{~min}$, effectiveness of biosorption increased rapidly and about $88 \%$ of zearalenone was bound to the bacterial cells. After it, the system has reached equilibrium stage. The calculated constant rate of the zero-order kinetic model had the value of $0.75 \mu \mathrm{g} /$ $\mathrm{mL} \min ^{-1}$ stage of described process. The ZEA biosorption by Bifidobacterium sp. is homogenous.

\section{Spectroscopic analysis of lactic acid bacteria after ZEA neutralization in the infrared range}

The aim of the FTIR study was to localize active chemical groups of bacterial proteins which contributed to the process of zearalenone uptake by Lactococcus lactis and Bifidobacterium sp.

The obtained FTIR spectra (Fig. 4) of zearalenone showed the presence of spectral bands at $v=1375 \mathrm{~cm}^{-1}$ (1) corresponding to the hydroxyl groups. Signal at $v=1455-$ $1460 \mathrm{~cm}^{-1}$ (2) derivate from the stretching vibrations of methyl group and the signal at $v=1540-1552 \mathrm{~cm}^{-1}$ (3) region from of phenyl ring vibration [29]. There are also peaks at

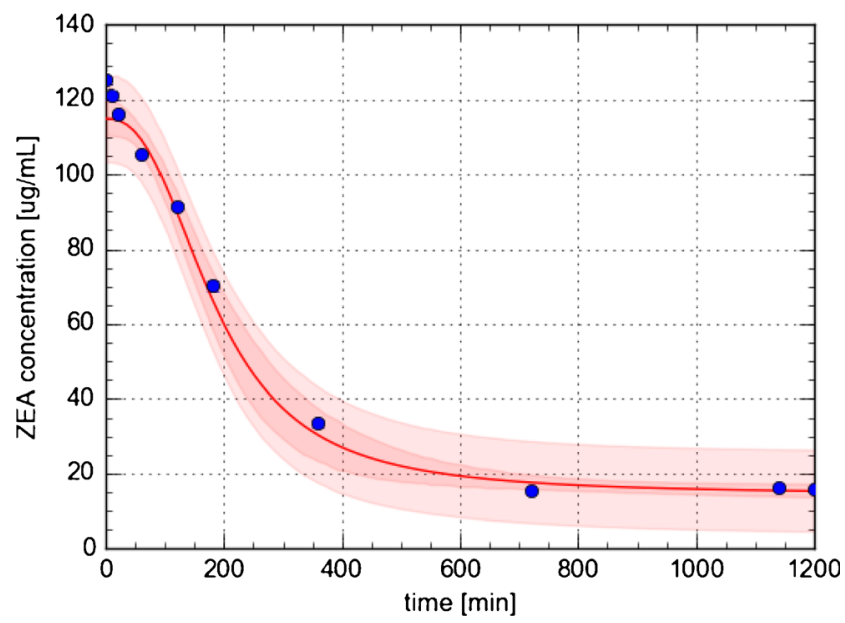

Fig. 3 Kinetics of zearalenone binding by Bifidobacterium $\mathrm{sp}$.; standard deviation $(\mathrm{SD})$ is shown as a red shadow

$v=1580-1590 \mathrm{~cm}^{-1}$ (4) and $1600-1615 \mathrm{~cm}^{-1}\left(4^{\prime}\right)$ corresponding to the ring $\mathrm{C}-\mathrm{C}$ stretching vibration [30]. Signals at $v=1650-1660 \mathrm{~cm}^{-1}$ (5), $v=1715 \mathrm{~cm}^{-1}$ (6), and $v=1735-1745 \mathrm{~cm}^{-1}$ (7) may be attributed to the carbonyl group of ZEA ring. Those results correspond with chemical structure of ZEA; the zearalenone molecule contains two reactive $-\mathrm{OH}$ groups on the benzene ring and two less reactive carbonyl groups on the 14-membered macrocyclic lactone ring [6].

According to the Naumann et al. [20], the analysis of bacteria FTIR spectra was focused on $v=1350-1850 \mathrm{~cm}^{-1}$ areas for amides groups. The FT-IR spectra of L. lactis after zearalenone neutralization is shown in Fig. 5a. There is a fission of signal at $v=1415-1460 \mathrm{~cm}^{-1}$ (1) at incubation time 720,1140 , and 1200 min respectively in comparison with spectral bands at shorter incubation time intervals. What is more, after 720, 1140, and 1200 min of incubation with ZEA, spectral bands at $v=1520-1560 \mathrm{~cm}^{-1}$ (2)

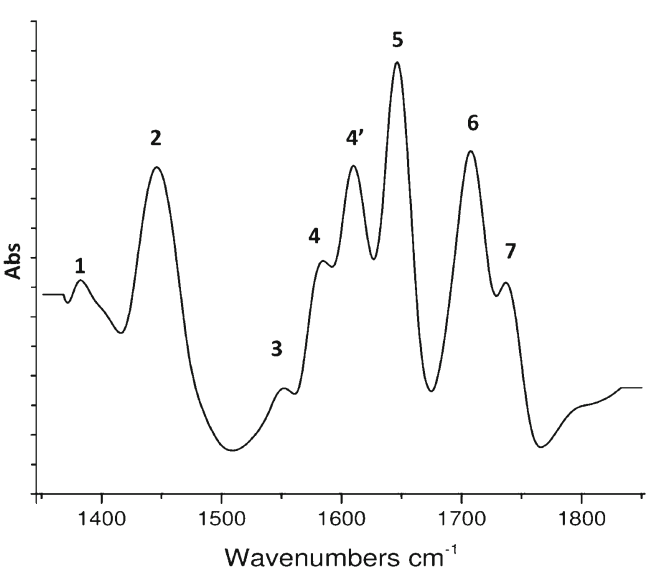

Fig. 4 FTIR spectra of zearalenone; $v\left[\mathrm{~cm}^{-1}\right]$ : $1: 1375-1385,2: 1455-$ 1460, 3: 1540-1552, 4: 1580-1590, 4': 1600-1615, 5: 1650-1660, 6: 1715-1720, 7: 1735-1745 


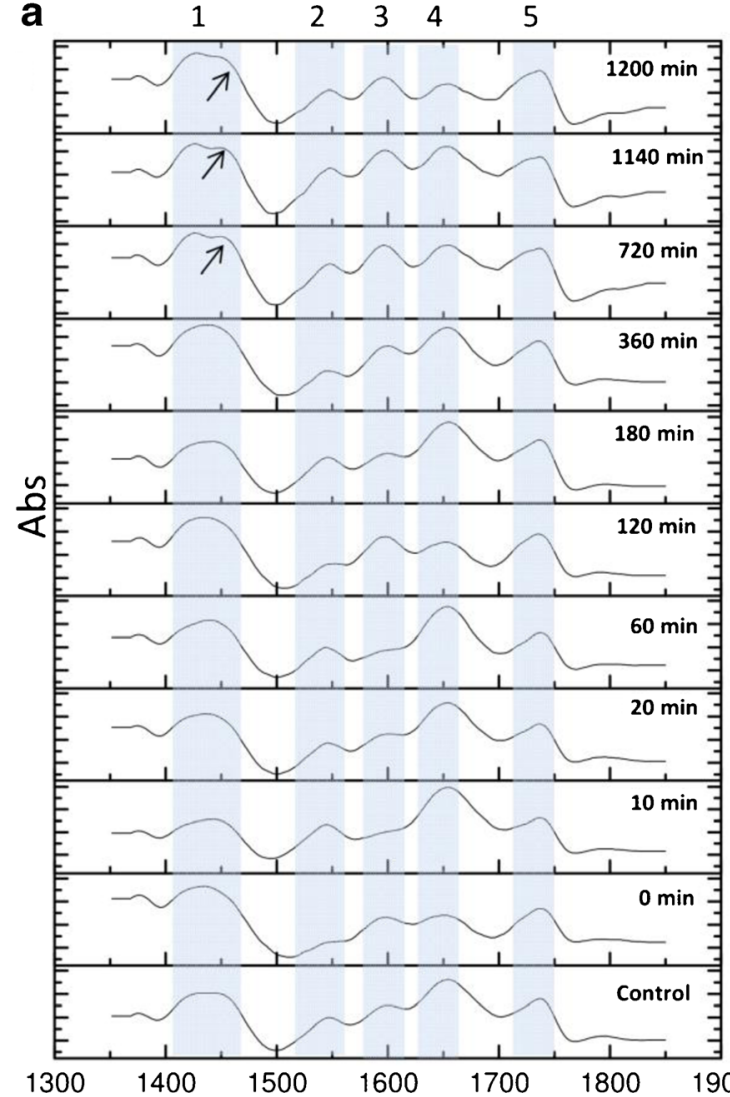

Fig. 5 (A) FT-IR spectra of Lactococcus lactis after zearalenone biosorption; $v\left[\mathrm{~cm}^{-1}\right]$ : 1: 1415-1460, 2: 1520-1560, 3: 1580-1620, 4: 1640-1660, 5: 1715-1750. (B) FT-IR spectra of Bifidobacterium sp. after

corresponding to the deprotonated carboxyl groups contribution for amid I on ZEA binding [30]. A signal at $v=1640$ $1660 \mathrm{~cm}^{-1}$ (4) and at $v=1715-1750 \mathrm{~cm}^{-1}$ (5) in each sample mean that they derived from stretching vibration of carbonyl groups $(\mathrm{C}=\mathrm{O})$ from amid II and III, respectively. Control band at $v(\max )=1600 \mathrm{~cm}^{-1}$ is shifted to $v(\max ) 1590 \mathrm{~cm}^{-1}$ $(v=1580-1620 ; 3)$ with the increase of ZEA incubation time. It is characterized by signal corresponding to the stretching vibrations of $\mathrm{C}=\mathrm{C}$ groups in aromatic ring of zearalenone; it indicates the biosorption of ZEA by L. lactis and involvement of $\pi-\pi$ interactions in uptake process. Furthermore, band at $v=1725 \mathrm{~cm}^{-1}(5)$ shows modification of $\mathrm{C}=\mathrm{O}$ group vibrations caused by influence of zearalenone on bacterial cell.

In comparison with control, the FTIR spectra of Bifidobacterium sp. after zearalenone binding (Fig. 5b), a signal at $v=1415-1460 \mathrm{~cm}^{-1}\left(1^{\prime}\right)$ is changed the band shape. These data correspond to results obtained in L. lactis after ZEA neutralization FTIR analysis. There is also spectra band at $v=1520-1560 \mathrm{~cm}^{-1}\left(2^{\prime}\right)$; this peak is related with stretching vibrations of $\mathrm{C}=\mathrm{C}$ group from the aromatic ring of zearalenone and point out occurrence of the biosorption process [30]. Signals at $v=1640-1660 \mathrm{~cm}^{-1}\left(3^{\prime}\right)$ and at $v=1730-1760 \mathrm{~cm}^{-1}\left(4^{\prime}\right)$ correspond to amides.

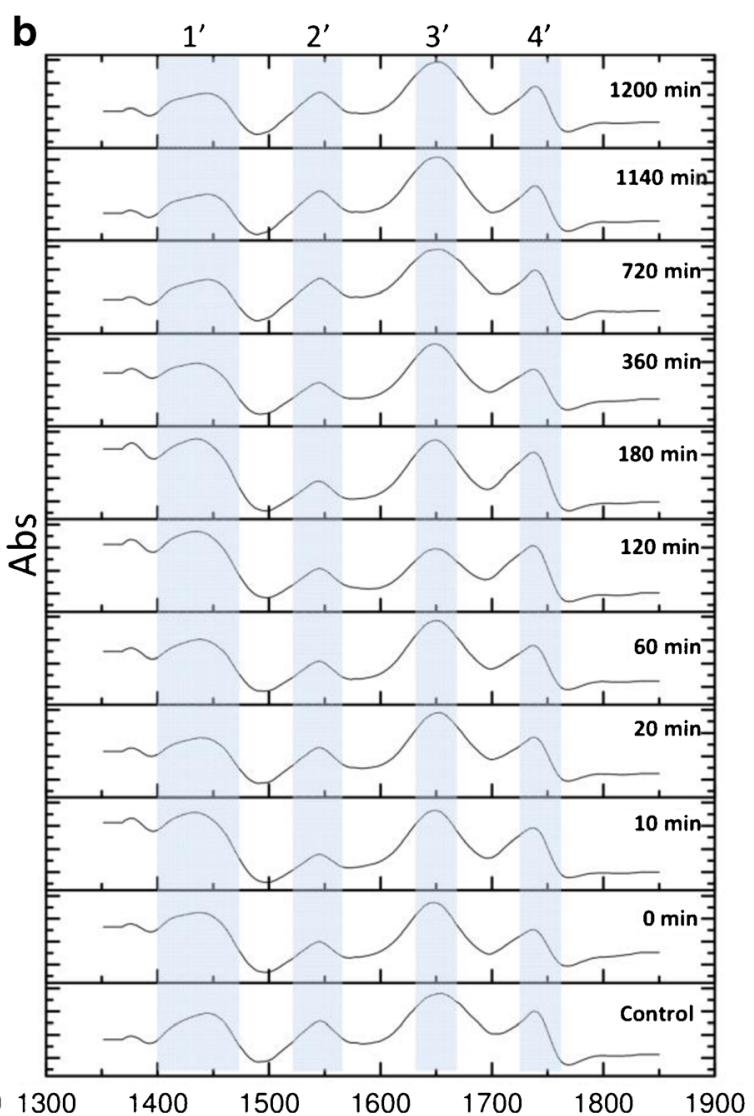

zearalenone biosorption; $v\left[\mathrm{~cm}^{-1}\right]: 1^{\prime}: 1415-1460,2^{\prime}: 1520-1560,3^{\prime}$ : 1640-1660, 4': 1730-1760

\section{Cells viability after ZEA neutralization}

To determine lactic acid bacteria cells after zearalenone biosorption, fluorescence-based cell viability method was chosen. To samples after 60 and $180 \mathrm{~min}$ of incubation, acridine orange, which is permeable for live and dead cells, and ethidium bromide (not permeable for live cells) were added. After staining, samples were detected with fluorescence microscopy; live cells exhibit green fluorescence and dead one are visible as a red [31,32].

L. lactis cells non-incubated with zearalenone, after 1 and $3 \mathrm{~h}$ incubation has been shown in Fig. 6a-c respectively. The fluorescent microscopy analysis indicated that with increasing incubation time, the number of dead bacterial cells is higher. Results of cell viability test for Bifidobacterium also showed the same correlation (Fig. 7d-f).

\section{MALDI-TOF-MS analysis for lactic acid bacteria after ZEA neutralization}

The MS spectra were recorded for the HCCA matrix, zearalenone, M9 minimal medium, bacteria not subjected to 

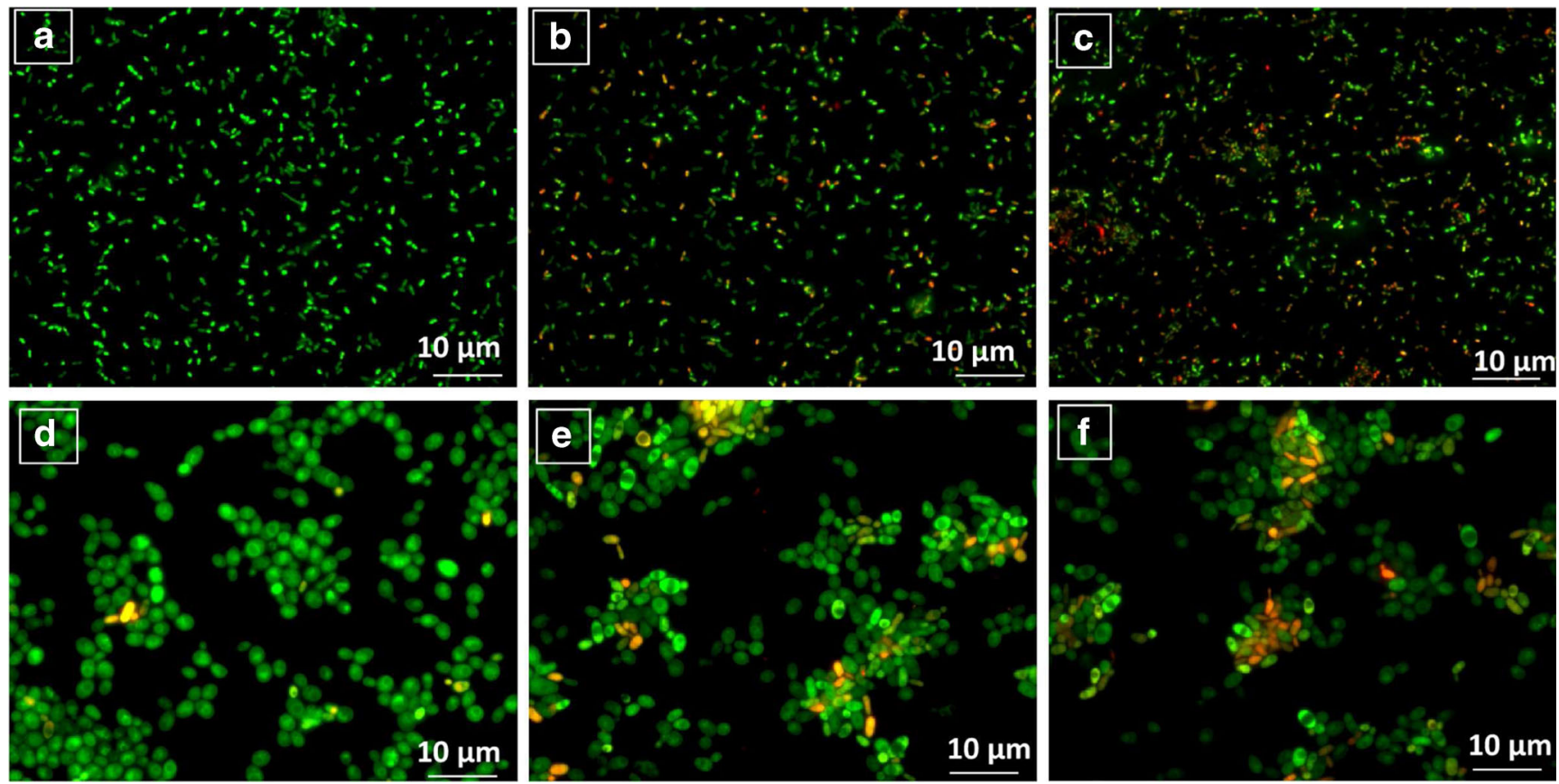

Fig. 6 Lactococcus lactis cells viability: (A) non-incubated with ZEA, (B) after $1 \mathrm{~h}$ of incubation with ZEA, (C) after $3 \mathrm{~h}$ of incubation with ZEA and Bifidobacterium sp. cells viability: (D) non-incubated with ZEA, (E) after $1 \mathrm{~h}$ of incubation with ZEA, (F) after $3 \mathrm{~h}$ of incubation with ZEA

the process of biosorption (negative control), and bacteria incubated with zearalenone, respectively.

From the table documenting the characteristic $\mathrm{m} / \mathrm{z}$ peaks of the MALDI-TOF spectrum for L. lactis (Table 1), the occurrence of new common signals for different incubation times and characteristic signals only for specific samples can be observed. In sample of bacteria incubated with ZEA for 0 , 10 , and $20 \mathrm{~min}$, a signal at $854 \mathrm{~m} / \mathrm{z}$ is present. Moreover, after $720 \mathrm{~min}$ of biosorption, a signal $(867 \mathrm{~m} / \mathrm{z})$ not occurring in the others samples appeared. After incubation time extension, peak at $1065 \mathrm{~m} / \mathrm{z}$ (for sample incubated for 0,10 , and $20 \mathrm{~min}$ ) and at $1081 \mathrm{~m} / \mathrm{z}(10$ and $20 \mathrm{~min})$ is disappeared. MALDI results of them have confirmed the presence of zearalenone molecules in the investigated bacteria samples.

According to the results of MALDI-TOF-MS analysis for Bifidobacterium sp., an occurrence of new peaks, characteristic only for the specific sample, can be observed (Table 2). Signals $2004,2290,2533$, and $2788 \mathrm{~m} / \mathrm{z}$ are present only in control sample (0 $\mathrm{min})$ without incubation with ZEA. Signal $384 \mathrm{~m} / \mathrm{z}$ disappeared after $60 \mathrm{~min}$ of incubation. Those results indicate the occurrence of a ZEA neutralization process conducted by lactic acid bacteria.

\section{Discussion}

The occurrence of mycotoxins in foods is dangerous for human health and it is considered as a major economic problem [9], so development of new and effective method of neutralization of zearalenone, an estrogenic compound and inductor of breast and prostate cancer, is required. Results obtained in this study confirmed neutralization of zearalenone by lactic acid bacteria such as L. lactis and Bifidobacterium sp. which is a new and promising approach to the microbiology neutralization of mycotoxins such as ZEA.

Results of kinetic studies indicate the rapid first stage of ZEA binding; in the first $720 \mathrm{~min}$ of biosorption by Bifidobacterium sp., the bacterial cell wall is saturated by ZEA. During this time, effectiveness of biosorption increased linear and about $88 \%$ of zearalenone is bound to the Bifidobacterium cells. Another mechanism is characteristic for $L$. lactis, where two different stages of ZEA sorption are observed; the first one is quite rapid (during the first $20 \mathrm{~min}$ about $90 \%$ of zearalenone were bound by LAB) and the second stage undergo system to equilibrium. Kinetic data are confirmed by constant rate of the zero-order kinetic model and can be related with the literature. In the work of Čvek et al. [25], the capacity of Lactobacillus rhamnosus and Lactobacillus plantarum for binding of zearalenone was investigated. The results show that about $98 \%$ of initial concentration $(20 \mu \mathrm{g} / \mathrm{mL})$ of ZEA from suspension has been attached to the cells of $L$. plantarum and between about $80 \%$ of ZEA has been bounded to the cells of $L$. rhamnosus at the beginning of incubation. After $72 \mathrm{~h}$ of incubation, the amount of ZEA in suspension has decreased slightly what can point out release of toxin back to the medium; the binding of zearalenone might be reversible process. Peltonen et al. [18] have tested the efficiency of aflatoxin B1 (AFB1) binding by lactic acid bacteria. Data from quantitation of aflatoxin $\mathrm{B} 1$ in supernatant samples by HPLC analysis pointed out that 


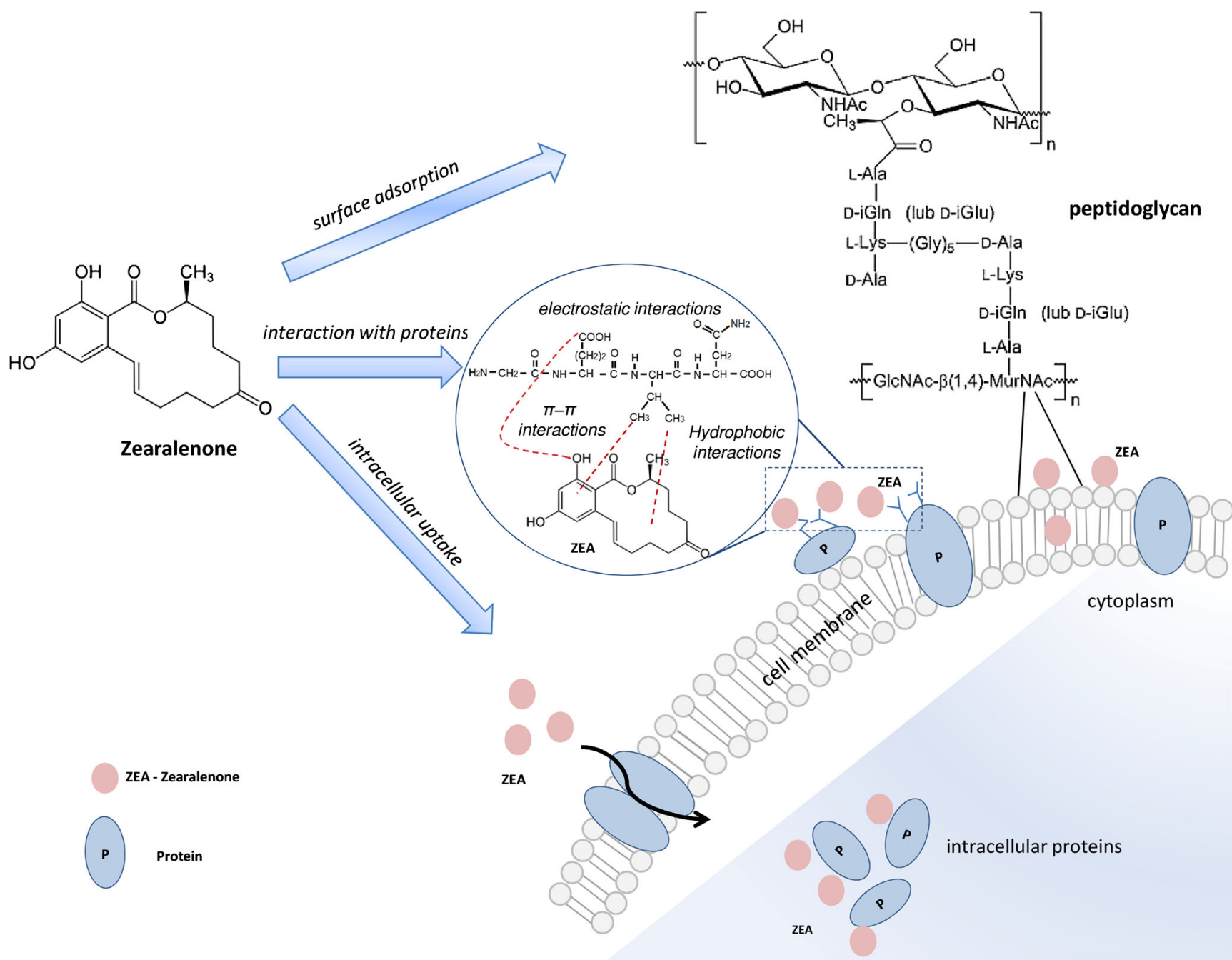

Fig. 7 The proposed mechanism of ZEA neutralization by L. lactis and Bifidobacterium sp.; ZEA can be adsorbed at the surface of bacteria and interact with the peptidoglycan or surface proteins or taken into bacterial cell

Lactobacillus, Bifidobacterium, and Lactococcus strains are able to binding AFB1 and bound 17.3 to $59.7 \%, 18.0$ to $48.7 \%$, and 5.6 to $41.1 \%$ of mentioned mycotoxin, respectively. Moreover, the efficient AFB1 binding by these strains was a rapid process; most of aflatoxin $\mathrm{B} 1$ were bound to $\mathrm{LAB}$ at first minutes of incubation. Those results

Table 1 List of characteristic peaks occurring in the MALD-TOF spectrum for Lactococcus lactis incubated with zearalenone during the 1200 min; signals mentioned in text are marked with a blue color

\begin{tabular}{|c|c|c|c|c|c|c|c|c|c|c|}
\hline $\mathbf{m} / \mathbf{z}$ & \multicolumn{9}{|c|}{ Time } \\
\hline & $\mathbf{0}$ min & $\mathbf{1 0}$ min & $\mathbf{2 0}$ min & $\mathbf{6 0}$ min & $\mathbf{1 2 0}$ min & $\mathbf{1 8 0}$ min & $\mathbf{3 6 0}$ min & $\mathbf{7 2 0}$ min & $\mathbf{1 1 4 0}$ min & $\mathbf{1 2 0 0}$ min \\
\hline $\mathbf{8 5 4}$ & + & + & + & & & & & & & \\
\hline $\mathbf{8 6 0}$ & + & + & + & + & + & + & + & & & \\
\hline $\mathbf{8 6 1}$ & & & & & & & & & + & + \\
\hline $\mathbf{8 6 7}$ & & & & & & & & + & + & + \\
\hline 1065 & + & + & + & & & & & & & \\
\hline 1081 & & + & + & & & & & & & \\
\hline 1292 & & + & & & & & & & & \\
\hline 1296 & & & & & & & & & & + \\
\hline 1340 & & & & & & & + & & & \\
\hline 1614 & & & & & & & & & & + \\
\hline
\end{tabular}


Table 2 List of characteristic peaks occurring in the MALD-TOF spectrum for Bifidobacterium sp. incubated with zearalenone during the 1200 min; signals mentioned in text are marked with a blue color

\begin{tabular}{|c|c|c|c|c|c|c|c|c|c|c|}
\hline $\mathbf{m} / \mathbf{z}$ & \multicolumn{10}{|c|}{ Time } \\
\hline & 0 min & $10 \mathrm{~min}$ & $20 \mathrm{~min}$ & $60 \mathrm{~min}$ & $120 \mathrm{~min}$ & $180 \mathrm{~min}$ & $360 \mathrm{~min}$ & $720 \mathrm{~min}$ & $1140 \mathrm{~min}$ & $1200 \mathrm{~min}$ \\
\hline 384 & + & + & + & + & & & & & & \\
\hline 397 & + & + & + & & + & + & & + & + & \\
\hline 401 & + & + & + & & + & + & + & + & + & + \\
\hline 1100 & + & + & + & + & + & + & + & + & + & + \\
\hline 1687 & + & + & + & + & + & + & + & + & + & + \\
\hline 2004 & + & & & & & & & & & \\
\hline 2290 & + & & & & & & & & & \\
\hline 2533 & + & & & & & & & & & \\
\hline 2788 & + & + & + & + & & & & + & & \\
\hline
\end{tabular}

correspond to data obtained in our study which also indicate rapid first stage of ZEA biosorption by Bifidobacterium sp. (during first $720 \mathrm{~min}$ ) and L. lactis (first $20 \mathrm{~min}$ of process). According to Weber-Morris model, the first rapid stage of ZEA sorption ( $80 \%)$ by L. lactis strain is limited by surface adsorption, and the second step (7\%) is determined by intracellular diffusion of zearalenone [33]. The different sorption mechanism of zearalenone results in different morphology of Bifidobacterium sp. and L. lactis, respectively. Moreover, the Bifidobacterium strains have a much more developed surface in comparison with $L$. lactis strains [34, 35]. Basing on the results, it may be concluded that the kinetics of zearalenone binding to lactic acid bacteria consists of distinct stages which correspond to different binding mechanisms. What is more, using a L. lactis and Bifidobacterium sp. strains allowed for the effective adsorption and neutralization of the zearalenone which is the solution to the problem of occurrence of dangerous mycotoxins in the i.e. food.

The proposed mechanism of ZEA neutralization by LAB is shown at the Fig. 7.

LAB are Gram-positive microorganisms with a cell wall which is a complex assemblage of glycopolymers and proteins. LAB cell wall contain about $95 \%$ of peptidoglycan - a polymer consisting of sugars and amino acids that forms a mesh-like layer outside the plasma membrane of the bacteria [36]. A major matrix substances in the walls of Gram-positive bacteria are polysaccharides, lipoteichoic (it is bound to the cell membrane by a diacylglycerol), and teichoic acid (bacterial copolymers of glycerol phosphate or ribitol phosphate and carbohydrates) [36-39]. Al components of the Gram-positive cell wall: peptidoglycan, teichoic acids, polysaccharides, and proteins, seem to be crucial in neutralization and binding of zearalenone to the lactic acid bacteria. Peltonen et al. [18] have reported that partial removal of mycotoxins involves physical binding of the toxin probably to the bacterial cell wall or cell wall components. Niderkorn et al. [40] have tested the ability of Lactobacillus paraplantarum to bind fumonisins B1 and
B2 (FB1, FB2) in fermented foods and feeds; furthermore, they tried to determine the bacterial cell wall component involved in binding mycotoxins. Results of the experiment showed that peptidoglycan and tricarballylic acid (TCA) chains of $\mathrm{LAB}$ and $\mathrm{FB}$, respectively, play a significant role in binding interactions; similar components of cell wall were also suggested for the binding of aflatoxin B1 by L. rhamnosus [41]. To identify potential functional groups and the possible adsorption sites related to adsorption of zearalenone by L. lactis and Bifidobacterium, FT-IR analysis was performed. Results of this assay indicate that the main groups involved in this binding process are deprotonated carboxyl groups (spectral bands at $v=1520-1560 \mathrm{~cm}^{-1}$ ) which can derive from both aminoacids (asparagine and glutamine) of bacterial proteins and peptidoglycan of their cell wall [32, 36-39]. Additionally, in biosorption of ZEA, $\pi-\pi$ hydrophobic interactions between zearalenone and LAB cells took place [42]. What is more, spectra band at $v=1580$ $1620 \mathrm{~cm}^{-1}$ (Fig. 5a) and $v=1520-1560 \mathrm{~cm}^{-1}$ (Fig. 5b) was observed; these peaks are related with stretching vibrations of $\mathrm{C}=\mathrm{C}$ group from the aromatic ring of zearalenone and point out occurrence of the biosorption process via $\pi-\pi$ hydrophobic interaction $[6,43]$. To confirm the zearalenone uptake by L. lactis and Bifidobacterium sp., the MALDI-TOF-MS analysis was conducted. The changes in appearancedisappearance of MS signals in function of time and their characteristic for peptides isotopic pattern suggest the contribution of peptides/proteins in immobilization process of ZEA by LAB. Kinetic data also confirmed the uptake of zearalenone by LABs and may prove the slow penetration of zearalenone into bacterial cells.

The mechanisms by which ZEA damage the cells are not completely understood, but there are some evidences $[14,15$, 27] of cytogenic effect and an apoptosis caused by zearalenone. Lioi et al. [44] have examined the induction of chromosome aberrations in in vitro bovine lymphocyte cultures treated with ZEA. It was also recently shown that ZEA 
increased DNA fragmentation in three cell lines, Vero, Caco2, and DOK, after $24 \mathrm{~h}$ exposure [45, 46]. Despite binding zearalenone to the components of bacterial cell wall, there is possibility of intracellular bioaccumulation and metabolization of ZEA [47-50]. As it is known, the biotransformation of ZEA involves the formation of $\alpha$-ZOL and $\beta$ $\mathrm{ZOL}$, and what is important, $\alpha-\mathrm{ZOL}$ shows higher estrogenicity than zearalenone [7, 8]. El-Sharkawy et al. [47] have studied the conversion of zearalenone by various microorganisms and results of their experiment showed that Streptomyces griseus, Streptomyces rutgersensus, and Rhizopus arrhizus were able to metabolize zearalenone to $\alpha$ zearalenol. In the work of Niderkorn et al. [48], eight Lactobacilli and three Leuconostoc strains biotransformed ZEA into $\alpha$-ZOL which point out the capability of lactic acid bacteria to the production of toxic zearalenone derivate. Intracellular uptake of ZEA and then metabolization of it can cause damages of bacterial cells and, in result, leads to death. To determine viability of lactic acid bacteria cells after ZEA neutralization, fluorescent microscopy approach was chosen. Data from this analysis indicated that with increasing incubation time, the number of dead bacterial cells is higher. Red fluorescent of bacterial cells after 1 and $3 \mathrm{~h}$ incubation with zearalenone can point out probable loss of cell membrane integrity, DNA damages and even death of L. lactis and Bifidobacterium cells which can be correlated in some extent with an intracellular accumulation of ZEA. This hypothesis can be confirmed by results from kinetic data where the second stage of ZEA neutralization may prove surface interaction and then the slow penetration of zearalenone into bacterial cells.

\section{Conclusions}

L. lactis and Bifidobacterium sp. strains isolated from milk products have the ability to adsorb and neutralize the zearalenone. Biosorption processes for analyzed bacterial strains are not the same. The sorption process performed by L. lactis in comparison with Bifidobacterium sp. cells is not homogeneous but is expressed with two main stages. The first one is quite rapid and consists of most of zearalenone biosorption ( $88 \%$ for L. lactis). The second stage is much slower and corresponds to the diffusion of ZEA into bacterial cells. In case of ZEA uptake process performed by Bifidobacterium sp., it is a one-step homogenous process. Results from FTIR analysis indicate that in neutralization of zearalenone by lactic acid bacteria, deprotonated carboxyl group (mainly from asparagine and glutamine) of bacterial proteins and peptidoglycan are mainly involved. According to the shown data, lactic acid bacteria seem to be promising alternatives for the development of new anti-mycotoxin agents.
Acknowledgments This work was supported by Maestro-6, No. 2014/14/A/ST4/00641 (2015-2017) and Opus 11 No. 2016/21/B/ST4/ 02130 (2017-2020) from the National Science Centre, Poland. We acknowledgment Agnieszka Pilińska, MSc for technical assistance in sample preparation and FTIR analysis.

\section{Compliance with ethical standards}

Conflict of interest The authors declare that they have no conflict of interest.

Open Access This article is distributed under the terms of the Creative Commons Attribution 4.0 International License (http:// creativecommons.org/licenses/by/4.0/), which permits unrestricted use, distribution, and reproduction in any medium, provided you give appropriate credit to the original author(s) and the source, provide a link to the Creative Commons license, and indicate if changes were made.

\section{References}

1. Van Der Fels-Klerx HJ, Klemsdal S, Hietaniemi V, Lindblad M, Ioannou-Kakouri E, Van Asselt ED. Mycotoxin contamination of cereal grain commodities in relation to climate in North West Europe. Food Addit Contam Part A. 2012;29:1581-92.

2. Rodrigues I, Naehrer K. A three-year survey on the worldwide occurrence of mycotoxins in feedstuffs and feed. Toxins. 2012;4: 663-75.

3. Hussein HS, Brasel JM. Toxicity, metabolism, and impact of mycotoxins on humans and animals. Toxicology. 2001;167:101-34.

4. Bennett JW, Klich M. Mycotoxins. Clin Microbiol Rev. 2003;16: 497-516.

5. Richard JL. Some major mycotoxins and their mycotoxicoses - an overview. Int J Food Microbiol. 2007;119:3-10.

6. Urry WH, Wehrmeister HL, Hodge EB, Hidy PH. The structure of zearalenone. Tetrahedron Lett. 1966;7:3109-14.

7. Malekinejad H, Maas-Bakker RF, Fink-Gremmels J. Bioactivation of zearalenone by porcine hepatic biotransformation. Vet Res. 2005;36:799-810.

8. Shier WT, Shier AC, Xie W, Mirocha CJ. Structure-activity relationships for human estrogenic activity in zearalenone mycotoxins. Toxicon. 2001;39:1435-8.

9. Legan JD. Mould spoilage of bread: the problem and some solutions. Int Biodeterior Biodegrad. 1993;32:33-53.

10. Paster N, Bullerman LB. Mould spoilage and mycotoxin formation in grains as controlled by physical means. Int J Food Microbiol. 1988;7:257-65.

11. Davidson PM, Taylor TM, Schmidt SE. Chemical preservatives and natural antimicrobial compounds. In: Doyle M, Beuchat L, editors. Food microbiology. Washington: ASM Press; 2013. p. 765-801.

12. Piotrowska M. Using of microorganisms for mycotoxin removal from food and feed. Postep Mikrobiol. 2012;51:109-19.

13. Magnusson J, Ström K, Roos S, Sjögren J, Schnürer J. Broad and complex antifungal activity among environmental isolates of lactic acid bacteria. FEMS Microbiol Lett. 2003;219:129-35.

14. Cho KJ, Kang JS, Cho WT, Lee CH, Ha JK, Song KB. In vitro degradation of zearalenone by Bacillus subtilis. Biotechnol Lett. 2010;32:1921-4.

15. Altalhi AD. Plasmid-mediated detoxification of mycotoxin zearalenone in Pseudomonas sp. ZEA-1. Am J Biochem Biotechnol. 2007;3:150-8. 
16. Varga J, Péteri Z, Tábori K, Téren J, Vágvölgyi C. Degradation of ochratoxin A and other mycotoxins by Rhizopus isolates. Int J Food Microbiol. 2005;99:321-8.

17. Fuchs S, Sontag G, Stidl R, Ehrlich V, Kundi M, Knasmüller S. Detoxification of patulin and ochratoxin A, two abundant mycotoxins, by lactic acid bacteria. Food Chem Toxicol. 2008;46:1398407.

18. Peltonen K, El-Nezami H, Haskard C, Ahokas J, Salminen S. Aflatoxin B1 binding by dairy strains of lactic acid bacteria and bifidobacteria. J Dairy Sci. 2001;84:2152-6.

19. El-Nezami H, Kankaanpaa P, Salminen S, Ahokas J. Ability of dairy strains of lactic acid bacteria to bind a common food carcinogen, aflatoxin B1. Food Chem Toxicol. 1998;36:321-6.

20. Dalié DKD, Deschamps AM, Richard-Forget F. Lactic acid bacteria - potential for control of mould growth and mycotoxins: a review. Food Control. 2010;21:370-80.

21. Keller L, Abrunhosa L, Keller K, Rosa CA, Cavaglieri L, Venâncio A. Zearalenone and its derivatives $\alpha$-zearalenol and $\beta$-zearalenol decontamination by Saccharomyces cerevisiae strains isolated from bovine forage. Toxins. 2015;7:3297-308.

22. Soomro AH, Masud T, Anwaar K. Role of lactic acid bacteria (LAB) in food preservation and human health-a review. Pak J Nutr. 2002;1:20-4.

23. Parvez S, Malik KA, Ah Kang S, Kim HY. Probiotics and their fermented food products are beneficial for health. J Appl Microbiol. 2006;100:1171-85.

24. Gilliland SE. Health and nutritional benefits from lactic acid bacteria. FEMS Microbiol Rev. 1990;7:175-88.

25. Čvek D, Markov K, Frece J, Friganović M, Duraković L, Delaš F. Adhesion of zearalenone to the surface of lactic acid bacteria cells. Hrvat čas za prehrambenu tehnol biotehnol nutr. 2012;7:49-52.

26. El-Nezami H, Polychronaki N, Lee YK, Haskard C, Juvonen R, Salminen S, et al. Chemical moieties and interactions involved in the binding of zearalenone to the surface of Lactobacillus rhamnosus strains GG. J Agric Food Chem. 2004;52:4577-81.

27. Shetty PH, Jespersen L. Saccharomyces cerevisiae and lactic acid bacteria as potential mycotoxin decontaminating agents. Trends Food Sci Technol. 2006;17:48-55.

28. Milanowski M, Pomastowski P, Railean-Plugaru V, Rafińska K, Ligor T, Buszewski B. Biosorption of silver cations onto Lactococcus lactis and Lactobacillus casei isolated from dairy products. PLoS One. 2017; doi:10.1371/journal.pone.0174521.

29. Naumann D, Keller S, Helm D, Schultz C, Schrader B. FT-IR spectroscopy and FT-Raman spectroscopy are powerful analytical tools for the non-invasive characterization of intact microbial cells. J Mol Struct. 1995;347:399-405.

30. Movasaghi Z, Shazza R. Ihtesham ur R. Fourier transform infrared (FTIR) spectroscopy of biological tissues. Appl Spectrosc Rev. 2008;43:134-79.

31. Robbins E, Marcus PI. Dynamics of acridine orange-cell interaction. J Cell Biol. 1963;18:237-50.

32. Baskić D, Popović S, Ristić P, Arsenijević NN. Analysis of cycloheximide-induced apoptosis in human leukocytes: fluorescence microscopy using annexin $\mathrm{V}$ /propidium iodide versus acridin orange/ethidium bromide. Cell Biol Int. 2006;30:924-32.

33. Pomastowski P, Sprynskyy M, Buszewski B. The study of zinc ions binding to casein. Colloids Surf B. 2014;120:21-7.
34. Samaržija D, Antunac N, Havranek JL. Taxonomy, physiology and growth of Lactococcus lactis: a review. Mljekarstvo. 2001;51:3548.

35. Poupard JA, Husain I, Norris RF. Biology of the bifidobacteria. Bacteriol Rev. 1973;37:136.

36. Chapot-Chartier MP, Kulakauskas S. Cell wall structure and function in lactic acid bacteria. Microb Cell Factories. 2014;13:9.

37. Wicken AJ, Knox KW. Lipoteichoic acids: a new class of bacterial antigen. Science. 1975;187:1161-7.

38. Weidenmaier C, Peschel A. Teichoic acids and related cell-wall glycopolymers in gram-positive physiology and host interactions. Nat Rev Microbiol. 2008;6:276-87.

39. Buszewski B, Dziubakiewicz E, Pomastowski P, Hrynkiewicz K, Płoszaj-Pyrak J, Talik E, et al. Assignment of functional groups in Gram-positive bacteria. J Anal Bioanal Tech. 2015;6:131.

40. Niderkorn V, Morgavi DP, Aboab B, Lemaire M, Boudra H. Cell wall component and mycotoxin moieties involved in the binding of fumonisin B1 and B2 by lactic acid bacteria. J Appl Microbiol. 2009; 106:977-85.

41. Lahtinen SJ, Haskard CA, Ouwehand AC, Salminen SJ, Ahokas JT. Binding of aflatoxin B1 to cell wall components of Lactobacillus rhamnosus strain GG. Food Addit Contam. 2004;21:158-64.

42. De Mil T, Devreese M, De Baere S, Van Ranst E, Eeckhout M, De Backer $\mathrm{P}$, et al. Characterization of 27 mycotoxin binders and the relation with in vitro zearalenone adsorption at a single concentration. Toxins. 2015;7:21-33.

43. Socrates G. Infrared and Raman characteristic group frequencies: tables and charts. Chichester: Wiley; 2004.

44. Lioi MB, Santoro A, Barbieri R, Salzano S, Ursini MV. Ochratoxin a and zearalenone: a comparative study on genotoxic effects and cell death induced in bovine lymphocytes. Mutat Res Genet Toxicol Environ Mutagen. 2004;557:19-27.

45. Abid-Essefi S, Ouanes Z, Hassen W, Baudrimont I, Creppy E, et al. Cytotoxicity, inhibition of DNA and protein syntheses and oxidative damage in cultured cells exposed to zearalenone. Toxicol in Vitro. 2004;18:467-74.

46. Abid-Essefi S, Baudrimont I, Hassen W, Ouanes Z, Mobio TA, Anane R, et al. DNA fragmentation, apoptosis and cell cycle arrest induced by zearalenone in cultured DOK, Vero and Caco-2 cells: prevention by vitamin E. Toxicology. 2003;192:237-48.

47. Kiessling KH, Pettersson H, Sandholm K, Olsen M. Metabolism of aflatoxin, ochratoxin, zearalenone, and three trichothecenes by intact rumen fluid, rumen protozoa, and rumen bacteria. Appl Environ Microbiol. 1984;47:1070-3.

48. Niderkorn V, Morgavi DP, Pujos E, Tissandier A, Boudra H. Screening of fermentative bacteria for their ability to bind and biotransform deoxynivalenol, zearalenone and fumonisins in an in vitro simulated corn silage model. Food Addit Contam. 2007;24:406-15.

49. Zinedine A, Soriano JM, Molto JC, Manes J. Review on the toxicity, occurrence, metabolism, detoxification, regulations and intake of zearalenone: an oestrogenic mycotoxin. Food Chem Toxicol. 2007:45:1-18.

50. Markov K, Frece J, Čvek D, Lovrić N, Delaš F. Aflatoxin M1 in raw milk and binding of aflatoxin lactic acid bacteria. Dairy. 2010;60:244-51. 